\title{
INTRASHELL RADIOCARBON VARIABILITY IN MARINE MOLLUSKS
}

\author{
Brendan J Culleton ${ }^{1,2} \bullet$ Douglas J Kennett ${ }^{1}$ B Lynn Ingram ${ }^{3} \bullet$ Jon M Erlandson $^{1,4} \bullet$ \\ John R Southon 5
}

ABSTRACT. We demonstrate variable radiocarbon content within 2 historic (AD 1936) and 2 prehistoric (about 8200 BP and 3500 BP) Mytilus californianus shells from the Santa Barbara Channel region, California, USA. Historic specimens from the mainland coast exhibit a greater range of intrashell variability (i.e. $180-240{ }^{14} \mathrm{C} \mathrm{yr}$ ) than archaeological specimens from Daisy Cave on San Miguel Island (i.e. $120{ }^{14} \mathrm{C}$ yr in both shells). $\delta^{13} \mathrm{C}$ and $\delta^{18} \mathrm{O}$ profiles are in general agreement with the upwelling of deep ocean water depleted in ${ }^{14} \mathrm{C}$ as a determinant of local marine reservoir correction $(\Delta \mathrm{R})$ in the San Miguel Island samples. Upwelling cycles are difficult to identify in the mainland specimens, where intrashell variations in ${ }^{14} \mathrm{C}$ content may be a complex product of oceanic mixing and periodic seasonal inputs of ${ }^{14} \mathrm{C}$-depeleted terrestrial runoff. Though the mechanisms controlling $\Delta \mathrm{R}$ at subannual to annual scales are not entirely clear, the fluctuations represent significant sources of random dating error in marine environments, particularly if a small section of shell is selected for accelerator mass spectrometry (AMS) dating. For maximum precision and accuracy in AMS dating of marine shells, we recommend that archaeologists, paleontologists, and ${ }^{14} \mathrm{C}$ lab personnel average out these variations by sampling across multiple increments of growth.

\section{INTRODUCTION}

The emergence of high-precision accelerator mass spectrometry (AMS) radiocarbon dating over the last decade has broadened the range of geological and archaeological materials that can be dated. Sample size requirements (grams of final carbon) for conventional ${ }^{14} \mathrm{C}$ dating often demanded composite or bulk-sampled charcoal, mollusk shell, or large sections of human or animal bone to obtain sufficient collagen, which decreases dating accuracy by averaging or precludes ${ }^{14} \mathrm{C}$ dating altogether for lack of suitable material. The micrograms of final carbon required for AMS dating are now routinely derived from specific genera of foraminifera (Hearty 2004; Ingram and Kennett 1995; Roark et al. 2003); annual tree-rings (Gandou et al. 2004; Kaiser 1994); pollen, starch grains, and seeds (Caran et al. 2001; Smith 1997; Mulholland and Prior 1993; Piperno and Flannery 2001; Piperno and Stothert 2003); small samples of bone collagen or specific amino acids (e.g. Formicola et al. 2004; Stafford et al. 1991; Taylor et al. 1998; Tripp and Hedges 2004); single mollusk valves (e.g. Ingram and Southon 1996; Kennett et al. 1997); and small shell artifacts (Erlandson et al. 2005; Fitzgerald et al. 2005; Rick et al. 2002; Vellanoweth 2001).

The small sample size requirements also offer several practical advantages to archaeologists. Researchers reluctant to part with unique, rare, or sensitive samples (e.g. a potentially early domesticated grain or human remains) may be willing to submit a small portion for destructive AMS dating. Associating the date acquired with the target event of interest (cf. Taylor 1987) is also aided in these cases by directly dating artifacts or ecofacts from complex stratigraphic contexts or human bones rather than burial goods, which may be subject to curation, reuse, and transmission, and hence may predate the burial event by several hundred years or more. Dating a short-lived sample is more likely to be realized and the old-wood effect (Erlandson et al. 1996; Kennett et al. 2002; Schiffer 1986) avoided if individual twigs can be selected from an ancient firepit rather than the inner growth increment of a large tree trunk. Such short-lived terrestrial samples are ideal for characterizing local

\footnotetext{
${ }^{1}$ Department of Anthropology, University of Oregon, Eugene, Oregon 97403-1218, USA.

${ }^{2}$ Corresponding author. Email: bculleto@uoregon.edu.

${ }^{3}$ Departments of Earth and Planetary Science and Geography, University of California, Berkeley, California 94720, USA.

${ }^{4}$ Museum of Natural and Cultural History, University of Oregon, Eugene, Oregon 97403-1224, USA.

${ }^{5}$ WM Keck Carbon Cycle AMS Facility, Earth System Science Department, University of California, Irvine, California 92697-3100, USA.
} 
marine and freshwater reservoirs when compared to associated archaeological shells in midden contexts, minimizing a source of potential dating error in aquatic settings (Culleton 2006; Fontugne et al. 2004; Ingram 1998; Kennett et al. 1997).

AMS dating of small marine shell artifacts, such as fishhooks, beads, and ornaments, has recently become widespread along the Pacific coast of California, as archaeologists seek to test chronologies established by artifact seriation (e.g. Bennyhoff and Hughes 1987; Gibson 1992; Gifford 1947; King 1990 ) and date the emergence of interregional trade networks (Erlandson et al. 2005; Fitzgerald et al. 2005; Groza 2002; Koerper et al. 1988, 1995; Rick 2001, 2005; Rick et al. 2002, 2005; Vellanoweth 2001; Vellanoweth et al. 2003). Several of these studies prove the analytic power of AMS dating, demonstrating that certain Olivella biplicata beads were traded along networks between the California coast and the Great Basin as early as 10,000-8000 cal BP (Erlandson et al. 2005; Fitzgerald et al. 2005) and that discrete interaction spheres described among ethnographic Uto-Aztecan groups may have existed as far back as 5500-4500 cal BP (Vellanoweth 2001). However, the promise of AMS dating artifacts made from portions of a whole shell comes with a devil's bargain; in exchange for a date on a small object, dating uncertainties may be introduced by the short-term variation in the mollusk's metabolism, habitat, and local ${ }^{14} \mathrm{C}$ reservoir (e.g. Dye 1994; Ingram 1998; Keith et al. 1964; Kennett et al. 1997; Killingley and Berger 1979; Krantz et al. 1987, 1989; Wefer and Berger 1991). Variations that are normally averaged in larger aggregate samples are potentially magnified by the random selection of a narrow period of growth. Here, we provide evidence of significant fluctuations in ${ }^{14} \mathrm{C}$ within historic and archaeological Mytilus californianus shells from California's Santa Barbara Channel region and examine the archaeological consequences for AMS dating of marine shell artifacts.

\section{METHODS AND MATERIALS}

Mytilus californianus shells were collected from CA-SMI-261 (Daisy Cave), a finely stratified shell midden deposit on the northeast coast of San Miguel Island (Figure 1), as part of a broader study that established the cave's Pleistocene to Holocene paleontological and cultural chronology (Erlandson et al. 1996; Kennett et al. 1997). Erlandson, Kennett, and colleagues used paired ${ }^{14} \mathrm{C}$ dates on shortlived charcoal samples (carbonized twigs) and mollusk shells (e.g. Haliotis rufescens, H. cracherodii, Tegula funebralis, Mytilus californianus) from closely associated contexts throughout the deposit to characterize fluctuations in the local marine reservoir correction $(\Delta \mathrm{R})$ between about 9500 to 3400 cal BP. Incremental samples (2-mm spacing; see below) were taken along 2 of these Mytilus valves, and $\delta^{18} \mathrm{O}$ and $\delta^{13} \mathrm{C}$ were measured using mass spectrometry (see Kennett et al. [1997] for methods and information regarding samples MC10: Column E6, Stratum E1; and MC11: Column E6, Stratum A3). Fluctuations in $\delta^{18} \mathrm{O}$ and $\delta^{13} \mathrm{C}$ were interpreted to reflect sea surface temperature (SST) and circulation changes due to seasonality and/or upwelling intensity. Six samples representing SST/upwelling maxima or minima were extracted for AMS ${ }^{14} \mathrm{C}$ dating (4 from MC10 and 2 from MC11) with a dental drill.

Two historic (pre-bomb) Mytilus californianus shells from the mainland coast were also obtained from the Santa Barbara Museum of Natural History. These specimens (\#43190 and \#431902) were from mollusks collected alive in AD 1936 (Figure 1). As with the archaeological specimens, these historical valves were incrementally sampled, and their $\delta^{18} \mathrm{O}$ and $\delta^{13} \mathrm{C}$ profiles were used to determine the sampling locations for AMS ${ }^{14} \mathrm{C}$ dating. Four AMS dates on each valve were obtained, and the average ${ }^{14} \mathrm{C}$ ages and $\Delta \mathrm{R}$ values for each valve are reported by Ingram and Southon (1996: Table 1) and used with other materials to establish the Santa Barbara Channel regional $\Delta \mathrm{R}$ of $233 \pm$ $60{ }^{14} \mathrm{C}$ yr. 


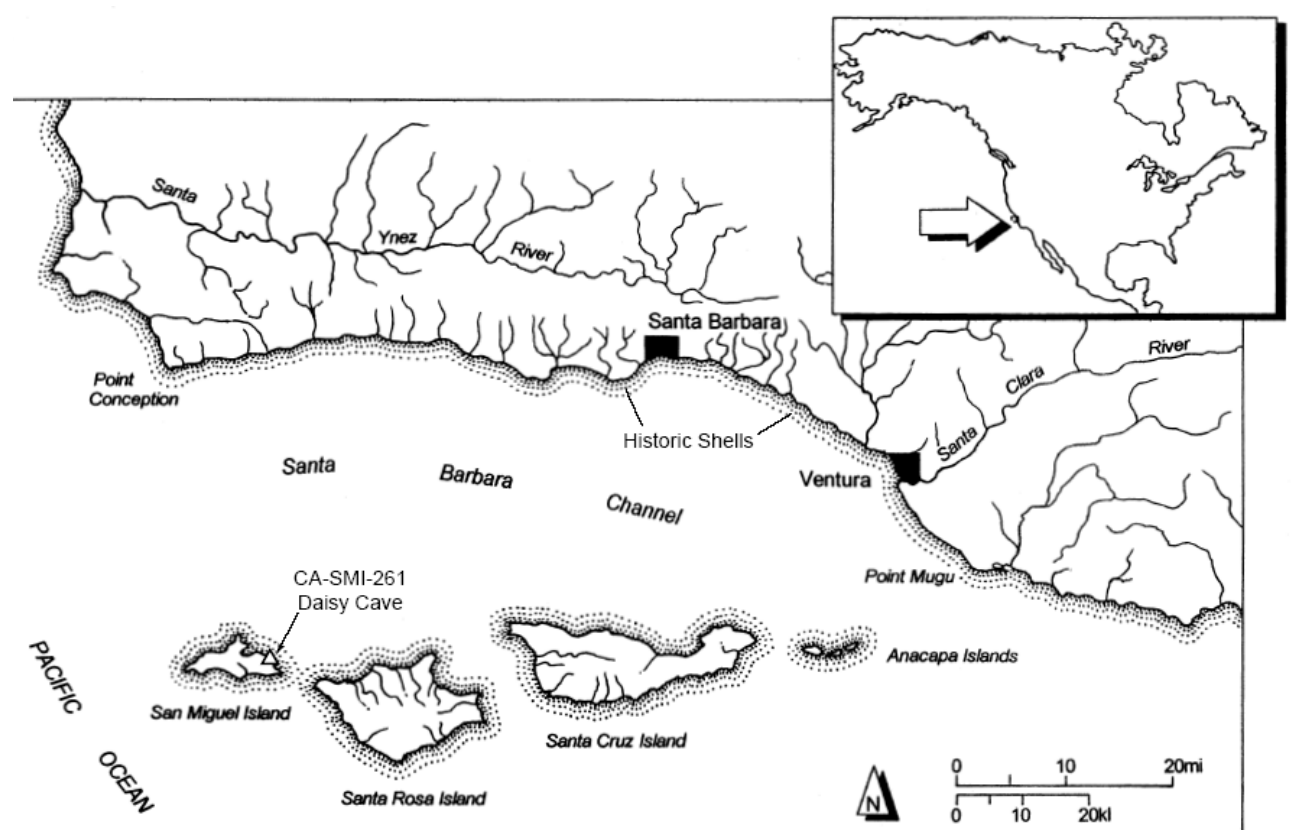

Figure 1 Map of the Santa Barbara Channel area. Archaeological Mytilus californianus shells were collected from CA-SMI-261 (Daisy Cave), and historic specimens were collected from the Santa Barbara coast in AD 1936.

\section{Oxygen and Carbon Isotopic Analysis}

Carbon and oxygen stable isotope profiles were taken from the shells under study to characterize proximate environmental conditions affecting their growth and development, specifically SST inferred from oxygen isotopes (Epstein et al. 1951, 1953; Glassow et al. 1994; Killingley 1981; Shackleton 1969, 1973) and upwelling intensity as derived from oxygen and carbon isotopes (Glassow et al. 1994; Killingley and Berger 1979; Wefer and Killingley 1980). Seasonal SST changes are recorded as relatively enriched $\delta^{18} \mathrm{O}$ values in colder water and depleted values in warmer water (Epstein et al. 1953). More intense upwelling should be accompanied by higher $\delta^{18} \mathrm{O}$ as colder deep water mixes with surface water. Decay of organic matter in deeper waters preferentially depletes ${ }^{13} \mathrm{C}$ in available dissolved inorganic carbon (DIC), which is partly offset by photosynthetic enrichment associated with increased surface productivity as nutrient-rich waters are upwelled (Killingley and Berger 1979). The result observed in Mytilus californianus from La Jolla, California, is a net lowering of $\delta^{13} \mathrm{C}$ during upwelling periods (Killingley and Berger 1979). Given the linkage between SST and upwelling intensity in southern California, $\delta^{13} \mathrm{C}$ and $\delta^{18} \mathrm{O}$ signals often covary inversely across a shell profile (cf. Glassow et al. 1994:229; Killingley and Berger 1979; Wefer and Berger 1991). Upwelling of deep ocean water is associated with older apparent ${ }^{14} \mathrm{C}$ age and larger $\Delta \mathrm{R}$ values because of slow mixing that leaves the global marine ${ }^{14} \mathrm{C}$ reservoir depleted relative to the atmosphere (Broecker and Peng 1980; Pak et al. 1997).

Most pre-bomb mollusks used to estimate $\Delta \mathrm{R}$ in eastern Pacific waters were derived from mainland beaches or estuarine settings where isotope values are more likely to be influenced by terrestrial runoff (Berger et al. 1966; Ingram and Southon 1996; Robinson and Trimble 1980; Taylor and Berger 1967). Freshwater inputs would lower shell $\delta^{13} \mathrm{C}$ and $\delta^{18} \mathrm{O}$ values, assuming that shells continued to grow with greater freshwater influences. Stream $\delta^{13} \mathrm{C}$ of DIC is typically depleted 5-10\%o compared to mean ocean water because of the decay of C3 plant material and soil processes (Keith et al. 1964), 
and $\delta^{18} \mathrm{O}$ is similarly depleted by fractionation during precipitation (Dansgaard 1964) and associated reduced salinity in continental waters (e.g. Ingram 1998; Kennett and Voorhies 1995). Along with the lowering of $\delta^{13} \mathrm{C}$ and $\delta^{18} \mathrm{O},{ }^{14} \mathrm{C}$-depleted carbon could be introduced from geologic sources (e.g. the Tertiary marine sediments in the Transverse Range north of Santa Barbara), increasing the mollusk's apparent ${ }^{14} \mathrm{C}$ age and estimated $\Delta \mathrm{R}$. Given these expectations, freshwater influence could be detected in an isotope profile as a divergence from the typical pattern of inverse covariation, where $\delta^{13} \mathrm{C}$ and $\delta^{18} \mathrm{O}$ both make negative excursions and $\Delta \mathrm{R}$ increases.

\section{Isotope Sampling Procedures}

Mytilus californianus shells were cleaned and rinsed with deionized water to remove visible organic material, and the periostracum was removed from the historical samples. Archaeological specimens were etched with $0.5 \mathrm{M} \mathrm{HCl}$ to remove diagenetically altered carbonate (Bailey et al. 1983). All shells were sectioned longitudinally, and calcite samples were extracted from the exterior prismatic layer in 2-mm increments along growth axes using a $0.5-\mathrm{mm}$ drill. Powdered calcite samples $(\sim 0.3$ $\mathrm{mg}$ ) were heated at $375^{\circ} \mathrm{C}$ under vacuum for $1 \mathrm{hr}$ to volatilize organic compounds. After cooling to room temperature, the samples were reacted with orthophosphoric acid at $90{ }^{\circ} \mathrm{C}$ using a Fairbanks common acid bath auto-sampling device. $\delta^{18} \mathrm{O}$ and $\delta^{13} \mathrm{C}$ of the evolved $\mathrm{CO}_{2}$ were measured using a Finnegan/MAT 251 mass spectrometer. All measurements are expressed in $\delta$ notation as the deviation from the PeeDee Belemnite (PDB) standard. The precision of $\delta^{13} \mathrm{C}$ and $\delta^{18} \mathrm{O}$ measurements is $0.1 \%$.

\section{${ }^{14} \mathrm{C}$ Analysis}

Carbonate samples ( $\sim 0.3 \mathrm{mg}$ ) were processed at the Lawrence Livermore National Laboratory Center for Accelerator Mass Spectrometry (LLNL-CAMS) (Davis et al. 1990). Calcite powder was evacuated to below 20 mTorr in a $10-\mathrm{mL}$ vacutainer and then reacted with $0.5 \mathrm{~mL}$ of phosphoric acid to generate $\mathrm{CO}_{2}$. Evolved carbon dioxide was reduced to graphite using a cobalt catalyst powder and $\mathrm{H}_{2}$ gas (Vogel et al. 1987). ${ }^{14} \mathrm{C} /{ }^{13} \mathrm{C}$ ratios were measured by AMS. ${ }^{14} \mathrm{C}$ ages were $\delta^{13} \mathrm{C}$-corrected for mass dependent fractionation with measured values (Stuiver and Polach 1977). $\Delta \mathrm{R}$ determinations were calculated by deducting the equivalent marine age (from Hughen et al. 2004) of stratigraphically associated charcoal samples from the conventional ${ }^{14} \mathrm{C}$ age of the shell sample (Stuiver et al. 1986; Stuiver and Braziunas 1993; converted charcoal ages reported in Kennett et al. 1997: Table 1).

\section{RESULTS}

$\delta^{18} \mathrm{O}$ and $\delta^{13} \mathrm{C}$ data for the 4 Mytilus valves are presented in Table 1 , and ${ }^{14} \mathrm{C}$ measurements and $\Delta \mathrm{R}$ calculations are presented in Table 2. Stable isotope profiles are plotted against $\Delta \mathrm{R}$ for each valve in Figures $2 \mathrm{~A}-\mathrm{D}$ to show the relationships between inferred environmental conditions and ${ }^{14} \mathrm{C}$ reservoir changes.

\section{Archaeological Specimens}

$\delta^{18} \mathrm{O}$ and $\delta^{13} \mathrm{C}$ profiles from the 2 Daisy Cave specimens (Figures $2 \mathrm{~A}-\mathrm{B}$ ) show the classic inverse relationship between upwelling (depleted $\delta^{13} \mathrm{C}$ ) and cooler SST (enriched $\delta^{18} \mathrm{O}$ ) previously observed in Mytlius californianus (e.g. Glassow et al. 1994; Killingley and Berger 1979). The average $\delta^{18} \mathrm{O}$ offset of $-0.6 \%$ between the Early Holocene MC 10 and the Middle Holocene MC11 is consistent with a decrease in ocean $\delta^{18} \mathrm{O}$ related to eustatic sea-level rise (Fairbanks 1989; Kennett et al. 1997). Both archaeological specimens record $\Delta \mathrm{R}$ fluctuations of up to $120{ }^{14} \mathrm{C} \mathrm{yr}$; the $\mathrm{MC} 10$ 
Table 1 Stable isotope results for incrementally sampled Mytilus californianus shells (Mean \pm SD).

\begin{tabular}{|c|c|c|c|c|c|c|c|}
\hline $\begin{array}{l}\text { Sample } \\
\# 43190^{\mathrm{a}}\end{array}$ & $\begin{array}{l}\text { Sample } \\
\text { increment } \\
(\mathrm{mm})\end{array}$ & $\delta^{18} \mathrm{O}$ & $\delta^{13} \mathrm{C}$ & $\begin{array}{l}\text { Sample } \\
\text { \#MC }^{\mathrm{b}}\end{array}$ & $\begin{array}{l}\text { Sample } \\
\text { increment } \\
(\mathrm{mm})\end{array}$ & $\delta^{18} \mathrm{O}$ & $\delta^{13} \mathrm{C}$ \\
\hline $\mathrm{a}$ & 0 & 0.548 & 0.578 & $11 \mathrm{a}$ & 0 & 0.454 & 0.762 \\
\hline $\mathrm{b}$ & 2 & 0.439 & 0.344 & $11 b$ & 2 & 0.135 & 0.800 \\
\hline $\mathrm{c}$ & 4 & 0.438 & 0.290 & $11 \mathrm{c}$ & 4 & -0.121 & 0.958 \\
\hline d & 6 & 0.107 & 0.356 & $11 d$ & 6 & -0.101 & 0.964 \\
\hline $\mathrm{e}$ & 8 & -0.252 & 0.474 & $11 \mathrm{e}$ & 8 & -0.267 & 0.989 \\
\hline $\mathrm{f}$ & 10 & -0.415 & 0.470 & $11 \mathrm{f}$ & 10 & -0.050 & 0.723 \\
\hline g & 12 & -0.384 & 0.241 & $11 \mathrm{~g}$ & 12 & 0.461 & 0.203 \\
\hline $\mathrm{h}$ & 14 & -0.503 & 0.234 & $11 \mathrm{~h}$ & 14 & 0.321 & 0.279 \\
\hline $\mathrm{i}$ & 16 & -0.214 & 0.452 & $11 \mathrm{i}$ & 16 & 0.390 & 0.048 \\
\hline $\mathrm{j}$ & 18 & -0.085 & 0.020 & $11 \mathrm{j}$ & 18 & 0.647 & -0.026 \\
\hline $\mathrm{k}$ & 20 & -0.199 & 0.376 & $11 \mathrm{k}$ & 20 & 0.543 & -0.104 \\
\hline 1 & 22 & -0.188 & 0.622 & 111 & 22 & 0.814 & -0.141 \\
\hline $\mathrm{m}$ & 24 & -0.217 & 0.472 & $11 \mathrm{~m}$ & 24 & 0.744 & -0.018 \\
\hline $\mathrm{n}$ & 26 & -0.292 & 0.236 & $11 \mathrm{n}$ & 26 & 0.299 & 0.703 \\
\hline o & 28 & -0.192 & 0.162 & 110 & 28 & 0.293 & 0.505 \\
\hline $\mathrm{p}$ & 30 & 0.049 & -0.121 & $11 p$ & 30 & 0.156 & 0.802 \\
\hline$q$ & 32 & 0.198 & -0.043 & $11 \mathrm{q}$ & 32 & 0.076 & 0.316 \\
\hline $\mathrm{r}$ & 34 & 0.168 & 0.329 & $11 \mathrm{r}$ & 34 & 0.051 & 0.718 \\
\hline $\mathrm{s}$ & 36 & -0.078 & 0.336 & $11 \mathrm{~s}$ & 36 & 0.162 & 0.589 \\
\hline $\mathrm{t}$ & 38 & 0.139 & 0.503 & & Mean & $0.26 \pm 0.30$ & $0.48 \pm 0.39$ \\
\hline \multirow[t]{2}{*}{$\mathrm{u}$} & 40 & 0.050 & 0.425 & & & & \\
\hline & Mean & $-0.04 \pm 0.29$ & $0.32 \pm 0.19$ & & & & \\
\hline $2 a$ & 0 & -0.333 & 0.429 & $10 \mathrm{a}$ & 0 & 1.079 & 0.614 \\
\hline $2 b$ & 2 & 0.372 & 0.109 & $10 \mathrm{~b}$ & 2 & 0.744 & 0.565 \\
\hline $2 c$ & 4 & 1.282 & 0.064 & $10 \mathrm{c}$ & 4 & 0.674 & 0.935 \\
\hline $2 d$ & 6 & -0.152 & 0.170 & $10 \mathrm{~d}$ & 6 & 0.595 & 0.831 \\
\hline $2 \mathrm{e}$ & 8 & 0.409 & -0.055 & $10 \mathrm{e}$ & 8 & 0.991 & 0.259 \\
\hline $2 \mathrm{f}$ & 10 & 0.759 & -0.071 & $10 f$ & 10 & 1.055 & -0.020 \\
\hline $2 g$ & 12 & 0.750 & 0.260 & $10 \mathrm{~g}$ & 12 & 0.884 & 0.513 \\
\hline $2 \mathrm{~h}$ & 14 & 0.768 & 0.222 & $10 \mathrm{~h}$ & 14 & 0.866 & 6.422 \\
\hline $2 \mathrm{i}$ & 16 & 0.706 & 0.136 & $10 \mathrm{i}$ & 16 & 0.679 & 0.737 \\
\hline $2 \mathrm{j}$ & 18 & 0.442 & 0.035 & $10 \mathrm{j}$ & 18 & 1.180 & -0.135 \\
\hline $2 \mathrm{k}$ & 20 & 0.657 & 0.181 & $10 \mathrm{k}$ & 20 & 1.239 & -0.385 \\
\hline 21 & 22 & 0.089 & -0.196 & 101 & 22 & 1.451 & 0.000 \\
\hline $2 \mathrm{~m}$ & 24 & -0.269 & 0.145 & $10 \mathrm{~m}$ & 24 & 1.358 & 0.219 \\
\hline $2 n$ & 26 & -0.456 & 0.042 & $10 n$ & 26 & 1.283 & 0.122 \\
\hline 20 & 28 & -0.220 & -0.277 & 100 & 28 & 1.124 & 0.372 \\
\hline $2 \mathrm{p}$ & 30 & 0.303 & -0.229 & $10 p$ & 30 & 0.918 & 0.623 \\
\hline $2 q$ & 32 & 0.335 & -0.268 & $10 \mathrm{q}$ & 32 & 0.734 & 0.940 \\
\hline $2 \mathrm{r}$ & 34 & 0.242 & -0.205 & $10 \mathrm{r}$ & 34 & 0.552 & 0.621 \\
\hline $2 \mathrm{~s}$ & 36 & 0.426 & -0.101 & $10 \mathrm{~s}$ & 36 & 0.351 & 0.791 \\
\hline \multirow[t]{2}{*}{$2 \mathrm{t}$} & 38 & 0.260 & -0.101 & & Mean & $0.93 \pm 0.30$ & $0.43 \pm 0.38$ \\
\hline & Mean & $0.32 \pm 0.44$ & $0.01 \pm 0.20$ & & & & \\
\hline
\end{tabular}

a Sample provenience: Santa Barbara, AD 1936.

${ }^{b}$ Provenience for sample 11-: CA-SMI-261: Unit D5, Str. A3. Provenience for sample 10-: CA-SMI-261: Unit D6, Str. E1. 
Table $2{ }^{14} \mathrm{C}$ results and $\Delta \mathrm{R}$ calculations for incrementally sampled Mytilus californianus shells.

\begin{tabular}{|c|c|c|c|c|c|c|c|c|}
\hline $\begin{array}{l}\text { Sample \# } \\
43190\end{array}$ & $\begin{array}{l}\text { Lab \# } \\
\text { CAMS- }\end{array}$ & Provenience & $\begin{array}{l}\text { Distance } \\
\text { from edge } \\
(\mathrm{mm})\end{array}$ & $\delta^{18} \mathrm{O}$ & $\delta^{13} \mathrm{C}$ & $\begin{array}{l}\text { Equivalent } \\
\text { marine age } \\
\left({ }^{14} \mathrm{C} \text { yr BP }\right)\end{array}$ & $\begin{array}{l}\text { Conventional } \\
{ }^{14} \mathrm{C} \text { age } \mathrm{BP}\end{array}$ & $\begin{array}{l}\Delta \mathrm{R} \\
\left({ }^{14} \mathrm{C} \text { yr }\right)\end{array}$ \\
\hline $43190 f$ & 6008 & Santa Barbara, & 10 & -0.415 & 0.470 & $458 \pm 23$ & $900 \pm 70$ & $440 \pm 70$ \\
\hline $43190 \mathrm{j}$ & 6007 & AD 1936 & 18 & 0.085 & 0.020 & $458 \pm 23$ & $720 \pm 60$ & $260 \pm 60$ \\
\hline 431901 & 6010 & & 22 & -0.188 & 0.622 & $458 \pm 23$ & $880 \pm 60$ & $420 \pm 60$ \\
\hline $43190 q$ & 6009 & & 32 & 0.198 & -0.043 & $458 \pm 23$ & $\begin{array}{r}790 \pm 60 \\
\text { Mean } \Delta R \\
\text { Range }\end{array}$ & $\begin{array}{l}330 \pm 60 \\
360 \pm 35 \\
180\end{array}$ \\
\hline $431902 \mathrm{c}$ & 14354 & Santa Barbara, & 4 & 1.282 & 0.064 & $458 \pm 23$ & $660 \pm 60$ & $200 \pm 60$ \\
\hline $431902 d$ & 14355 & $\mathrm{AD} 1$ & 6 & -0.152 & 0.170 & $458 \pm 23$ & $900 \pm 60$ & $440 \pm 60$ \\
\hline $431902 \mathrm{~g}$ & 14356 & & 12 & 0.750 & 0.260 & $458 \pm 23$ & $680 \pm 60$ & $220 \pm 60$ \\
\hline $431902 n$ & 14357 & & 26 & -0.456 & 0.042 & $458 \pm 23$ & $\begin{array}{r}700 \pm 60 \\
\text { Mean } \Delta R \\
\text { Range }\end{array}$ & $\begin{array}{l}240 \pm 60 \\
275 \pm 45 \\
240\end{array}$ \\
\hline MC11e & 14358 & CA-SMI-261: & 8 & -0.267 & 0.989 & $3460 \pm 60$ & $3820 \pm 80$ & $360 \pm 100$ \\
\hline MC111 & 14359 & Unit D5, Str. A3 & 22 & 0.814 & -0.141 & $3460 \pm 60$ & $\begin{array}{r}3940 \pm 70 \\
\text { Mean } \Delta R \\
\text { Range }\end{array}$ & $\begin{array}{l}480 \pm 90 \\
430 \pm 50 \\
120\end{array}$ \\
\hline MC10d & 14360 & CA-SMI-261: & 6 & 0.595 & 0.831 & $8150 \pm 60$ & $8440 \pm 80$ & $290 \pm 100$ \\
\hline MC10f & 14361 & Unit D6, Str. E1 & 10 & 1.055 & -0.020 & $8150 \pm 60$ & $8500 \pm 80$ & $350 \pm 100$ \\
\hline MC10i & 14379 & & 16 & 0.679 & 0.737 & $8150 \pm 60$ & $8380 \pm 60$ & $230 \pm 85$ \\
\hline MC101 & 14380 & & 22 & 1.451 & 0.000 & $8150 \pm 60$ & $\begin{array}{r}8400 \pm 60 \\
\text { Mean } \Delta R \\
\text { Range }\end{array}$ & $\begin{array}{l}250 \pm 85 \\
270 \pm 35 \\
120\end{array}$ \\
\hline
\end{tabular}

samples range from $230 \pm 85$ to $350 \pm 100{ }^{14} \mathrm{C}$ yr at $8150 \pm 60 \mathrm{BP}$ (CAMS-8866), and the MC11 samples range from $360 \pm 100$ to $480 \pm 90{ }^{14} \mathrm{C}$ yr at $3460 \pm 60 \mathrm{BP}$ (CAMS-9095). $\Delta \mathrm{R}$ trends generally follow the expectation that $\Delta \mathrm{R}$ increases with the upwelling of ${ }^{14} \mathrm{C}$-depleted deep ocean water, but the relationship is not exact. Declining $\Delta \mathrm{R}$ between the $2{ }^{14} \mathrm{C}$ measurements in MC 11 (Figure $2 \mathrm{~A}$ ) is consistent with better surface layer mixing as upwelling declines (higher $\delta^{13} \mathrm{C}$ ) and SST increases (lower $\delta^{18} \mathrm{O}$ ). An inferred period of upwelling in MC10 (Figure 2B) at the 10-mm increment is also accompanied by a peak in $\Delta \mathrm{R}\left(350{ }^{14} \mathrm{C} \mathrm{yr}\right)$, but what appears to be a more intense upwelling episode centered around $20 \mathrm{~mm}$, based on $\delta^{18} \mathrm{O}$ and $\delta^{13} \mathrm{C}$, is correlated with lower $\Delta \mathrm{R}$ values $\left(250{ }^{14} \mathrm{C}\right.$ yr at $22 \mathrm{~mm}$ and $230{ }^{14} \mathrm{C}$ yr at $\left.18 \mathrm{~mm}\right)$.

The low ${ }^{14} \mathrm{C}$ sampling resolution likely misses the detailed character of $\Delta \mathrm{R}$ shifts in these shells, so it is possible that the ${ }^{14} \mathrm{C}$ age is primarily affected by upwelling. However, our data suggest that the picture is more complex. In particular, $\Delta \mathrm{R}$ values in MC11 are much higher than was determined for the same stratum at Daisy Cave by Kennett et al. (1997). While the mean value for MC $10(\Delta \mathrm{R}=$ $\left.270 \pm 35{ }^{14} \mathrm{C} \mathrm{yr}\right)$ is similar to that obtained on Haliotis cracherodii from Col. E6, Str. E1 $(\Delta \mathrm{R}=310$ ${ }^{14} \mathrm{C}$ yr at $\left.8150 \pm 60 \mathrm{BP}\right)$, the mean $\Delta \mathrm{R}$ value for $\mathrm{MC} 11$ of $430 \pm 50{ }^{14} \mathrm{C}$ yr diverges widely from $\Delta \mathrm{R}=$ $-30{ }^{14} \mathrm{C}$ yr in Haliotis rufescens from Col. E6, Str. A3 (Kennett et al. 1997: Table 1). The 2 values at $3460 \pm 60 \mathrm{BP}$ represent extremes of marine ${ }^{14} \mathrm{C}$ reservoir conditions, either equaling or doubling the global ocean age $(R)$ of $400{ }^{14} \mathrm{C}$ yr (Stuiver et al. 1986). Short-term (e.g. decadal scale), largemagnitude shifts in upwelling intensity or other climatic variables could be responsible for the 

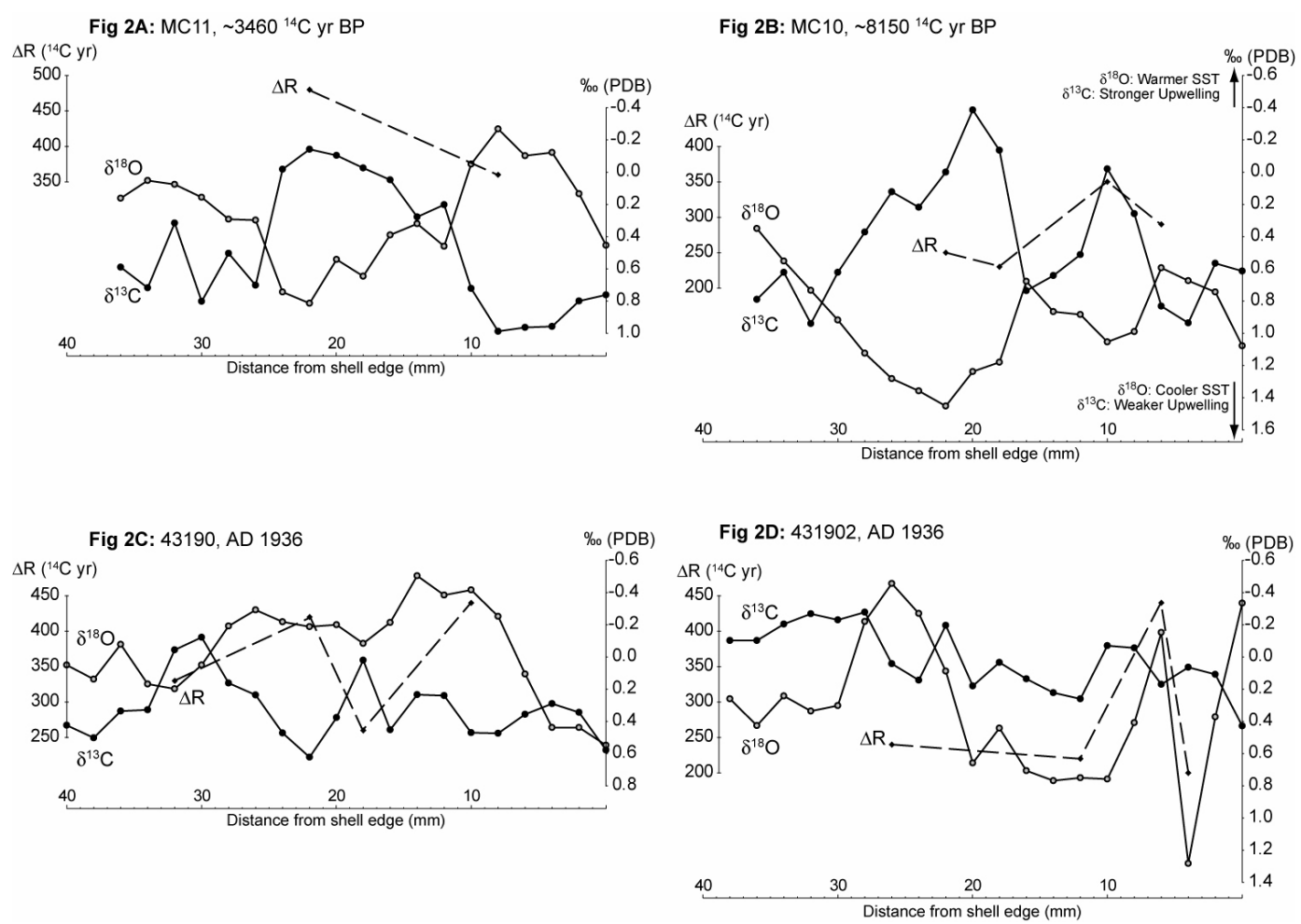

Figure 2 Stable isotope and $\Delta \mathrm{R}$ profiles of incrementally sampled archaeological (A, B) and historic (C, D) Mytilus californianus shells from the Santa Barbara Channel.

observed variation. The 2 data points are only suggestive, but it is worth noting that Santa Barbara Channel SST recorded by $\delta^{18} \mathrm{O}$ of Globigerina bulloides in the ODP Site 893A/B is highly variable (i.e. exhibits a high coefficient of variation at 50-yr intervals) between about 4000-3000 cal BP (Kennett 2005: Figure 11). Variable SST at that time correlates with fluctuating vertical stratification reflected in the difference between $\delta^{18} \mathrm{O}$ values of surface-dwelling G. bulloides and thermoclinal Neogloboquadrina pachyderma (Kennett et al., forthcoming). Rapid shifts in upwelling intensity, and hence marine productivity, during this period may be responsible for the observed variability in $\Delta \mathrm{R}$. Further paired charcoal and shell AMS dates may clarify the linkages between ocean SST, ocean circulation, and the ${ }^{14} \mathrm{C}$ reservoir through the Holocene. For now, it is clear that dated archaeological samples from about $3500 \mathrm{BP}$ may be accompanied by large but poorly characterized errors.

\section{Historic Specimens}

$\delta^{18} \mathrm{O}$ and $\delta^{13} \mathrm{C}$ profiles in the historic specimens do not appear to reflect seasonal upwelling cycles, or at least they are too ambiguous to define if present (Figures 2C-D). Possible upwelling events may be recorded in \#43190 at 30-32 mm and $18 \mathrm{~mm}$ (Figure 2C) and in \#431902 from 38-28 mm (Figure 2D), but these are equivocal. In addition, these shells exhibit a greater $\Delta \mathrm{R}$ range than the prehistoric samples: $180{ }^{14} \mathrm{C}$ yr in \#43190 $\left(260 \pm 60-440 \pm 70{ }^{14} \mathrm{C}\right.$ yr $)$ and $240{ }^{14} \mathrm{C}$ yr in $\# 431902$ $\left(200 \pm 60-440 \pm 60{ }^{14} \mathrm{C} \mathrm{yr}\right)$. The $\Delta \mathrm{R}$ fluctuations are not consistent with the hypothesis that seasonal fluctuations in $\Delta \mathrm{R}$ are driven by the upwelling of ${ }^{14} \mathrm{C}$-depleted deep ocean water, as for the most part lower $\Delta R$ values are associated with higher $\delta^{18} \mathrm{O}$ values. Overall, the relationship between 
$\Delta \mathrm{R}$ and stable carbon and oxygen isotopes is more erratic than those from Daisy Cave, suggesting major differences in ocean circulation or terrestrial ${ }^{14} \mathrm{C}$ influences between the offshore Channel Islands and the continental mainland.

The 2 historic Mytilus californianus samples are presumed to have been live-collected together in AD 1936 somewhere along the coast near Santa Barbara, though the Santa Barbara Museum of Natural History catalog does not record these details. If so, we would expect some similarity in seasonal isotopic signatures, though shell growth typically slows with age, compressing these signals later in life (e.g. Killingley 1981; Shackleton 1973). Composite stable isotope and $\Delta \mathrm{R}$ profiles for the 2 shells are depicted in Figure 3, which were scaled to match common features of the $2 \delta^{13} \mathrm{C}$ curves. Depleted values at \#43190 (32-30 mm) and \#431902 (22 mm) and variation in \#43190 (16-0 mm) and \#431902 (12-0 mm) are taken to be analogous. Stable isotope curves are roughly averaged (heavy dashed lines in Figures $3 \mathrm{~A}-\mathrm{B}$ ), and $\Delta \mathrm{R}$ values are plotted at the revised scale as single points (open triangles and diamonds). Two $\Delta \mathrm{R}$ pairs that show good agreement in magnitude and timing between the 2 shells are averaged (closed triangles), and the composite $\Delta \mathrm{R}$ signal generally appears to be consistent with fairly regular seasonal variations. Yet $\Delta \mathrm{R}$ shifts are inconsistent with an upwelling mechanism, as lower average $\delta^{13} \mathrm{C}$ is matched with lower $\Delta \mathrm{R}$ (Figure $3 \mathrm{~A}$ ) and higher $\Delta \mathrm{R}$ tracks warmer SST in the later half of the $\delta^{18} \mathrm{O}$ curve (Figure 3B), the opposite of expectations. One possible explanation is that these data reflect seasonal inputs of terrestrial runoff composed of isotopically light water and ${ }^{14} \mathrm{C}$-depleted carbon dissolved from the Tertiary marine sediments north and east of the Santa Barbara Channel. This would be consistent with the mainland setting where the shells were collected. Streams and rivers in Santa Barbara and Ventura counties are typically full between January and April and often run dry in late summer and fall (USGS NWIS 2006). Wet season runoff would decrease shell $\delta^{18} \mathrm{O}$ by lowering water $\delta^{18} \mathrm{O}$ and salinity in estuaries, and to a lesser extent, in open-shore habitats. Freshwater ${ }^{14} \mathrm{C}$ reservoir ages are not available for coastal streams, but Berger and Meek (1992) report a ${ }^{14} \mathrm{C}$ age on pre-bomb freshwater mussels (Anodonta californiensis) from the Mojave Basin and a pond in East Lake Park on the Santa Clara River in Los Angeles. Correcting for the shell mixture and atmosphere age, Culleton (2006) recalculated the freshwater reservoir as $310{ }^{14} \mathrm{C}$ yr for the sample. Assuming similar geology in the adjacent watersheds, it is reasonable to assume that these streams seasonally deliver a ${ }^{14} \mathrm{C}$-depleted load of dissolved inorganic carbon into peri-coastal marine environments, as has been demonstrated in San Francisco Bay (Ingram 1998).

Two observations suggest that the intrashell variability in $\Delta \mathrm{R}$ is a complex product of both marine and terrestrial systems. First, though the $\delta^{18} \mathrm{O} / \Delta \mathrm{R}$ pattern shows tight agreement for the later half of the combined curve, the earlier part appears to show the opposite trend: $\Delta \mathrm{R}$ and $\delta^{18} \mathrm{O}$ increasing together (Figure 3B). This is more consistent with the hypothesis that these apparent ages are a result of the upwelling of ${ }^{14} \mathrm{C}$-depleted water. Second, terrestrial runoff should have heavily depleted $\delta^{13} \mathrm{C}$ values along with depleted ${ }^{14} \mathrm{C}$ and $\delta^{18} \mathrm{O}$ (Keith and Anderson 1963; Keith et al. 1964). This is not evident in this isotopic profile. Modern $\delta^{13} \mathrm{C}$ of particulate organic matter in Santa Barbara area streams reflects decomposed C3 plant biomass at about -26\% PDB (Santa Barbara Coastal LongTerm Ecological Research 2003:38-39), and this should register in the isotopic composition of these mollusk shells if they are sensitively recording water $\delta^{18} \mathrm{O}$ that is depleted $\sim 8-10 \%$ (standard mean ocean water [SMOW]) relative to ocean water (Kendall and Coplen 2001). This complexity is significant to our understanding of global ocean circulation and carbon cycling because the vast majority of local reservoir corrections are determined using mainland specimens. More detailed studies using the 3 isotope systems (i.e. ${ }^{14} \mathrm{C} /{ }^{12} \mathrm{C},{ }^{13} \mathrm{C} /{ }^{12} \mathrm{C}$, and ${ }^{18} \mathrm{O} /{ }^{16} \mathrm{O}$ ) may clarify the varying influences of marine and terrestrial carbon inputs in other nearshore environments. 
Fig 3A.

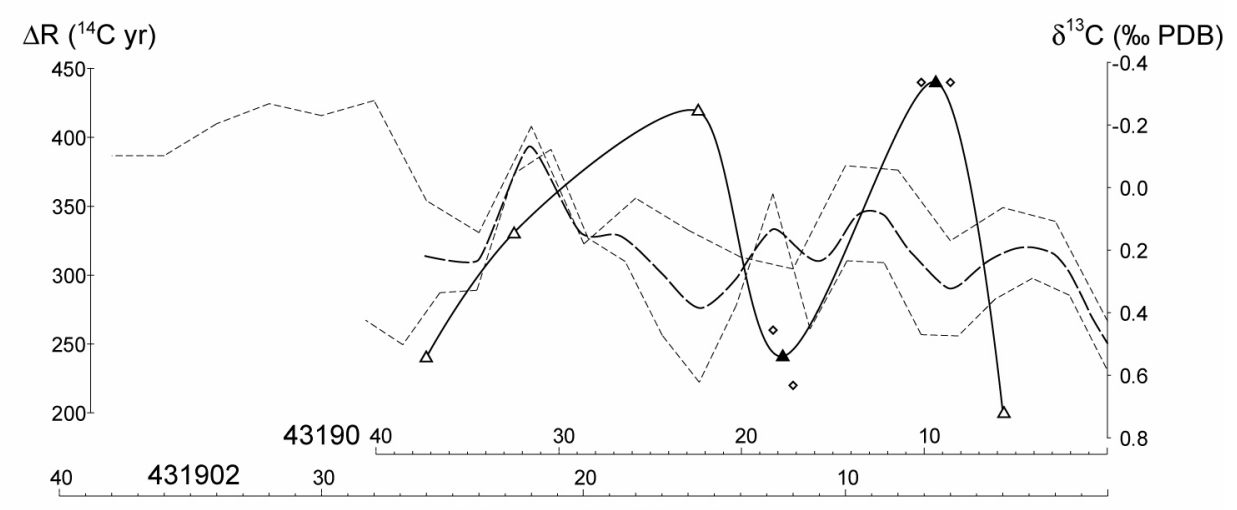

Fig 3B.

Distance from shell edge $(\mathrm{mm})$

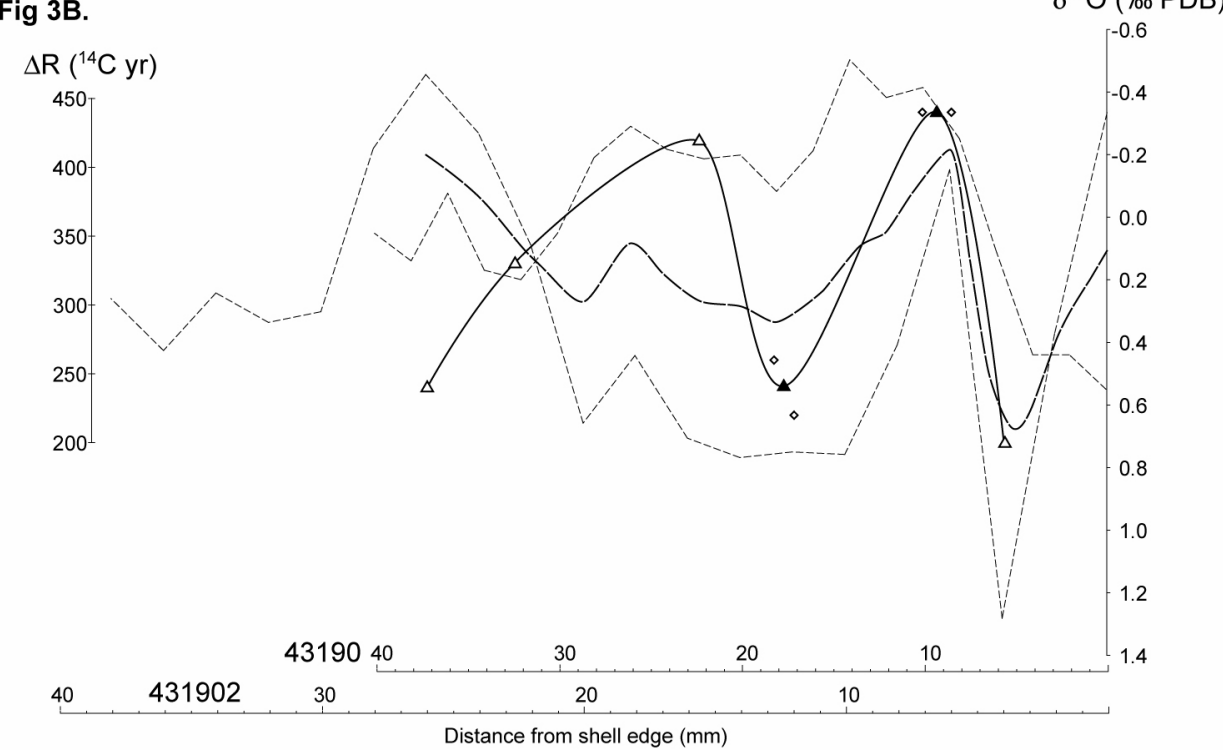

Figure 3 Composite $\Delta R$ profiles versus (A) $\delta^{13} \mathrm{C}$ and (B) $\delta^{18} \mathrm{O}$ in 2 historic Mytilus californianus shells from the Santa Barbara coast. Profiles were scaled using similar features of the $\delta^{13} \mathrm{C}$ curves. Stable isotope curves are roughly averaged (heavy dashed lines), and $\Delta \mathrm{R}$ is plotted as single points (open triangles and diamonds) or averages (closed triangles).

\section{IMPLICATIONS FOR ARCHAEOLOGISTS}

With the increasing use of AMS for high-precision ${ }^{14} \mathrm{C}$ dating, annual to seasonal changes in $\Delta \mathrm{R}$ on the scale of $100-200{ }^{14} \mathrm{C}$ yr represent significant sources of random dating error for archaeologists working in aquatic settings. This error is especially problematic if a small fragment of a shell artifact is selected to minimize loss of material, or if the artifact itself is only a small portion of a much larger shell. To take a hypothetical example, if 2 small (5-mm diameter) M. californianus disk beads were manufactured from one of the shells analyzed in this study $\left(\mathrm{MC} 10 ; 8150 \pm 60{ }^{14} \mathrm{C} \mathrm{BP}\right)$, one centered at $10 \mathrm{~mm}$ and the other at $16 \mathrm{~mm}$ from the terminal growth margin, they would produce significantly different calibrated ${ }^{14} \mathrm{C}$ ages. Assuming an average $\Delta \mathrm{R}$ of $230 \pm 40{ }^{14} \mathrm{C}$ yr (i.e. $225 \pm 35{ }^{14} \mathrm{C}$ yr, Berger et al. 1967; $233 \pm 60{ }^{14} \mathrm{C}$ yr, Ingram and Southon 1996) and measurement precision of \pm 30 
${ }^{14} \mathrm{C}$ yr, the $1-\sigma$ calibrated ages would be $8860-8690 \mathrm{cal} \mathrm{BP}$ at $10 \mathrm{~mm}$ and $8710-8540 \mathrm{cal} \mathrm{BP}$ at $16 \mathrm{~mm}$ (Stuiver and Reimer 1993; Stuiver et al. 1998, 2000). With only 20 cal yr of overlap, archaeologists might infer that the 2 beads were made 100 or more years apart when in fact they are contemporary. If there is something distinctive about their form or manufacture (e.g. the edges are incised), which is simply idiosyncratic to the beadmaker on that day in the Early Holocene, a new bead tradition spanning a few centuries could be erected with significant cultural-historical implications. This might seem a far-fetched scenario at first glance, but the most fine-grained and widely cited shell bead typologies in California, Bennyhoff and Hughes (1987) and King (1990), divide Late Holocene cultural phases into 200-yr increments based on Olivella bead forms. Direct AMS dating of diagnostic Olivella beads has found general concordance with these chronologies (Groza 2002), but random $\Delta \mathrm{R}$ fluctuations on the order of centuries suggests that this sort of temporal resolution may be illusory. As archaeologists seek to increase chronometric precision in hopes of matching the temporal resolution of historical, cultural, and environmental records in California (e.g. Culleton 2006; Kennett and Kennett 2000), careful evaluation of all sources of dating error should be made and appropriate sampling procedures adopted.

\section{Recommendations for Sampling Marine Shell Artifacts}

Given the intrashell $\Delta \mathrm{R}$ variability evident in marine mollusk shells, the best approach for AMS ${ }^{14} \mathrm{C}$ dating of such shells is to homogenize samples to average short-term fluctuations in the local marine ${ }^{14} \mathrm{C}$ reservoir ages. Larger, faster growing shells present the greatest potential for sampling error (e.g. California mussel, Mytilus californianus; abalone, Haliotis sp.; Pismo clam, Tivela stultorum). Within an individual, shell grown later in the animal's life will tend to average annual or seasonal variation per length of shell as accretion slows. Most gastropod shells are laid down cumulatively rather than laterally, such as the lip of an abalone (Haliotis sp.) or the callus and columella of the olive snail (Olivella sp.), which concentrates several years of growth in a small area, making them good candidates for obtaining well-averaged samples. Regardless, a good sample for dating should be taken along a substantial portion $(\sim 1-2 \mathrm{~cm})$ of the growth axis of the shell rather than perpendicular to it. When choosing among valve fragments, the distal portion of a larger, older individual is preferable to the proximal end of a younger, faster-growing individual.

In California, native peoples used a variety of mollusks including Haliotis sp., Mytilus sp., Olivella sp., Ostrea sp., Saxidomus sp., and Tivela sp. to produce disk beads and ornaments ranging from 3 to $20 \mathrm{~mm}$ in diameter (e.g. Bennyhoff and Hughes 1987; King 1990; Rick 2004). Olivella shows the greatest diversity of bead forms, from a nearly whole condition (spire-removed) as early as 10,000 cal BP (Erlandson et al. 2005; Fitzgerald et al. 2005), as split half-shells after 1500 cal BP (King 1990), as tiny callus beads after 700 cal BP (Arnold 1992; King 1990), and numerous other forms throughout the Holocene (Bennyhoff and Hughes 1987; King 1990). Depending on the bead type, an archaeologist may not have many sampling options, but usually the growth axis can be identified and an appropriately averaged sample can be taken even from small specimens. A small (3-4 mm) Olivella bead made from the body whorl (e.g. Bennyhoff and Hughes' G2 Tiny Saucer) is among the least favorable sampling situations; the best that can be done is to date half the bead split along the growth axis. In contrast, an equally small Olivella callus bead is a ready-made, time-averaged specimen and should pose no special problems.

Shell fish hooks are another common artifact found in coastal settings. Among the maritime peoples of coastal California, determining the chronology of technological change is key to understanding the role of economic intensification and the emergence of social complexity in the Late Holocene (e.g. Kennett 2005; Koerper et al. 1988, 1995; Rick 2001; Rick et al. 2002). Various J- to C-shaped forms made from Mytilus or Haliotis shell are well-described in the Santa Barbara Channel region 
(Glassow 1996), ranging from 10-50 $\mathrm{mm}$ in maximum dimension. As such, a fish hook often represents a broad period of shell growth, and the approach of sampling along the axis may be used if the outer prismatic layer of the shell (which accretes laterally) is preserved. However, many hooks comprise only the laminated nacreous shell layer, so time-averaging the sample may require cutting a section perpendicular to the laminations or drilling through them. Whatever the shell or artifact, sampling should attempt to average out short-term yet significant temporal variations in ${ }^{14} \mathrm{C}$ content, which requires careful observation of the growth habits and structure of the organism under study.

Aquatic resources played a crucial subsistence role in the evolution and global dispersal of anatomically modern humans during the last 40,000 yr, well within the range of AMS dating (Erlandson 2001). Exploring the nature of early aquatic adaptations depends upon establishing viable chronologies, and marine mollusk shells are among the most ubiquitous and durable archaeological remains recovered from coastal sites around the world. In some coastal settings, the prehistoric use of old driftwood for fuel precludes its use in dating, leaving marine shells as the preferred material for chronology building (Erlandson et al. 1996; Kennett et al. 2002). Beyond establishing chronologies of subsistence and settlement via AMS ${ }^{14} \mathrm{C}$ dating, the appearance of possible shell ornaments in the Middle Paleolithic of North Africa and the Levant suggests that with improvements in the precision and accuracy of the AMS technique, archaeologists may document the emergence of the cognitive ability and symbolic behavior that is the hallmark of our species today (Vanhaeren et al. 2006). Establishing confidence in the timing of these events and their situation within paleoclimatic and paleoecological frameworks will be bolstered by the careful sampling strategies described here.

\section{CONCLUSIONS}

As initially developed, ${ }^{14} \mathrm{C}$ dating was based on a set of assumptions that have turned out to be only partly correct. Careful analysis has provided a series of techniques to correct for these problems, and technical advances have increased the precision and accuracy of ${ }^{14} \mathrm{C}$ dating. Some of these advances, however, have created new problems that continue to require further study and methodological adjustments. In this paper, we addressed one such problem, significant internal variation in the ${ }^{14} \mathrm{C}$ content of individual growth bands of California mussel shells, a marine bivalve widely used by archaeologists along the Pacific coast of North America for ${ }^{14} \mathrm{C}$ dating. For AMS ${ }^{14} \mathrm{C}$ dating, we have shown that the common practice of submitting a small shell fragment or drilling a sample for dating from a single location along the growth axis of a California mussel shell can produce dates a century or more different from the true age of a sample. Similar problems can be expected for many marine mollusk shells, especially those found in coastal settings marked by seasonal fluctuations in upwelling or freshwater input.

Rather than discouraging researchers from dating marine shells-which have proven to provide reliable dates when well-preserved samples are pretreated, analyzed, and interpreted correctly-we offer a simple solution to this problem. When preparing to submit or process marine shells for AMS analysis, archaeologists and ${ }^{14} \mathrm{C}$ laboratory personnel should sample parts of a shell that are not susceptible to such problems or sample multiple growth bands to obtain an average age for the sample.

\section{ACKNOWLEDGMENTS}

This work was supported in part by the National Science Foundation (SBR-9521974; DJK) and a National Science Foundation Graduate Research Fellowship (BJC). AMS dating was carried out at LLNL-CAMS with support from a Global Change Distinguished Postdoctoral Fellowship (BLI), sponsored by the US Department of Energy, Office of Health and Environmental Research, administered by the Oak Ridge Institute for Science and Education. We wish to thank Paul V Scott, Cura- 
tor of Malacology at the Santa Barbara Museum of Natural History for providing the historical Mytilus californianus shells used in this study. Original field work at Daisy Cave was facilitated by Don Morris and the Channel Islands National Park. A special thanks to James Kennett and his isotope laboratory staff at the University of California, Santa Barbara for their support and encouragement. Finally, we want to thank an anonymous reviewer and the editors of Radiocarbon for their constructive comments and assistance in the revision and production of this paper.

\section{REFERENCES}

Arnold JE. 1992. Complex hunter-gatherer-fishers of prehistoric California: chiefs, specialists, and maritime adaptations of the Channel Islands. American Antiquity 57:60-84.

Bailey GN, Deith MR, Shackleton NJ. 1983. Oxygen isotope analysis and seasonality determinations: limits and potential of a new technique. American Antiquity 48(2):390-8.

Bennyhoff J, Hughes R. 1987. Shell bead and ornament exchange networks between California and the Great Basin. Anthropological Papers of the American Museum of Natural History 64(2):80-175.

Berger R, Meek N. 1992. Radiocarbon dating of Anodonta in the Mojave River basin. Radiocarbon 34(3): 578-84.

Berger R, Taylor RE, Libby WF. 1966. Radiocarbon content of marine shells from the California and Mexican west coast. Science 153:864-6.

Broecker WS, Peng TS. 1980. Seasonal variability in the C14/C12 ratio for surface ocean water. Geophysical Research Letters 7(11):1020-2.

Caran SC, Winsborough BM, Valastro S, Neely JA, Anderson RS. 2001. Radiocarbon chronology of carbonate deposits; reliable dating using organic residues. Abstracts with Programs - Geological Society of America 33(6):254.

Culleton BJ. 2006. Implications of a freshwater radiocarbon reservoir correction for the timing of late Holocene settlement of the Elk Hills, Kern County, California. Journal of Archaeological Science 33:1331-9.

Dansgaard W. 1964. Stable isotopes in precipitation. Tellus 16(4):436-68.

Davis JC, Proctor ID, Southon JR, Caffee MW, Heikkinen DW, Robers ML, Moore TL, Turteltaub KW, Nelson DE, Loyd DH, Vogel JS. 1990. LLNL/UC AMS facility and research program. Nuclear Instruments and Methods in Physics Research B 52(3-4):269-72.

Druffel ERM, Seuss HA.1983. On the radiocarbon record in banded corals: exchange parameters and net transport of $\mathrm{CO}_{2}$ between the atmosphere and surface ocean. Journal of Geophysical Research 88:1271-80.

Dye T. 1994. Apparent ages of marine shells: implications for archaeological dating in Hawai'i. Radiocarbon 36(1):51-7.

Epstein S, Buchsbaum R, Lowenstam H, Urey H. 1951. Carbonate-water isotopic temperature scale. Bulletin of the Geological Society of America 62:417-26.

Epstein S, Buchsbaum R, Lowenstam H, Urey H. 1953.
Revised carbonate-water isotopic temperature scale. Bulletin of the Geological Society of America 64: 1315-26.

Erlandson JM, Kennett DJ, Ingram BL, Guthrie DA, Morris DP, Tveskov MA, West GJ, Walker PL. 1996. An archaeological and paleontological chronology for Daisy Cave (CA-SMI-261), San Miguel Island, California. Radiocarbon 38(2):355-73.

Erlandson JM, Macko ME, Koerper HC, Southon JR. 2005. The antiquity of Olivella shell beads at CAORA-64: AMS radiocarbon dated between 9420 and 7780 cal BP. Journal of Archaeological Science 32: 393-8.

Fairbanks RG. 1989. A 17,000-year glacio-eustatic sea level record: influence of glacial melting rates on the Younger Dryas event and deep-ocean circulation. $\mathrm{Na}$ ture 342:637-41.

Fitzgerald RT, Jones TL, Schroth A. 2005. Ancient longdistance trade in western North America: new AMS radiocarbon dates from southern California. Journal of Archaeological Science 32:423-34.

Fontugne M, Carré M, Bentaleb I, Julien M, Lavallé D. 2004. Radiocarbon reservoir age variations in the south Peruvian upwelling during the Holocene. $\mathrm{Ra}$ diocarbon 46(2):531-7.

Formicola V, Pettitt PB, Del Lucchese A. 2004. A direct AMS radiocarbon date on the Berma Grande 6 Upper Paleolithic skeleton. Current Anthropology 45(1): 114-8.

Gandou T, Sakurai H, Katoh W, Takahashi Y, Gunji S, Tokonai F, Matsuzaki H. 2004. ${ }^{14} \mathrm{C}$ concentrations of single-year tree rings from about 22,000 years ago obtained using a highly accurate measuring method. $R a-$ diocarbon 46(2):949-55.

Gibson RO. 1992. An introduction to the study of aboriginal beads from California. Pacific Coast Archaeological Society Quarterly 28(3):1-45.

Gifford EW. 1947. Californian shell artifacts. University of California Anthropological Records 9(1):1-114.

Glassow MA. 1996. Purisimeno Chumash Prehistory: Maritime Adaptations Along the Southern California Coast. Fort Worth, Texas: Harcourt Brace College. $170 \mathrm{p}$.

Glassow MA, Kennett DJ, Kennett JP, Wilcoxon LR. 1994. Confirmation of middle Holocene ocean cooling inferred from stable isotopic analysis of prehistoric shells from Santa Cruz Island, California. In: Halvorson WL, Maender GJ, editors. The Fourth Cal- 
ifornia Islands Symposium: Update and the Status of Resources. Santa Barbara, California: Santa Barbara Museum of Natural History. p 223-32.

Groza RG. 2002. An AMS chronology for central California Olivella shell beads [unpublished Master's thesis]. San Francisco: San Francisco State University.

Hearty PJ, O'Leary MJ, Kaufman DS, Page MC, Bright J. 2004. Amino acid geochronology of individual foraminifer (Pulleniatina obliquiloculata) tests, north Queensland Margin, Australia; a new approach to correlating and dating Quaternary tropical marine sediments. Paleoceanography 19(4). PA4022. doi: 10.1029/2004PA001059.

Hughen KA, Baillie MGL, Bard E, Bayliss A, Beck JW, Bertrand C, Blackwell PG, Buck CE, Burr G, Cutler KB, Damon PE, Edwards RL, Fairbanks RG, Friedrich M, Guilderson TP, Kromer B, McCormac FG, Manning S, Bronk Ramsey C, Reimer PJ, Reimer RW, Remmele S, Southon JR, Stuiver M, Talamo S, Taylor FW, van der Plicht J, Weyhenmeyer CE. 2004. Marine04, marine radiocarbon age calibration, 0-26 cal kyr BP. Radiocarbon 46(3):1059-86.

Ingram BL. 1998. Differences in radiocarbon age between shell and charcoal from a Holocene shellmound in northern California. Quaternary Research 49:102-10.

Ingram BL, Kennett JP. 1995. Radiocarbon chronology and planktonic-foraminiferal ${ }^{14} \mathrm{C}$ age differences in Santa Barbara Basin sediments, Hole 893A. In: Kennett JP, Baldauf JG, Lyle M, editors. Proceedings of the Ocean Drilling Program, Scientific Results. Volume 146, Part 2. p 19-27.

Ingram BL, Southon JR. 1996. Reservoir ages in eastern Pacific coastal and estuarine waters. Radiocarbon 38(3):573-82.

Kaiser KF. 1994. Two Creeks interstade dated through dendrochronology and AMS. Quaternary Research 42(3):288-98.

Keith ML, Anderson GM. 1963. Radiocarbon dating: fictitious results with mollusk shells. Science 141:634-7.

Keith ML, Anderson GM, Eichler R. 1964. Carbon and oxygen isotopic composition of mollusk shells from marine and freshwater environments. Geochimica et Cosmochimica Acta 28:1757-86.

Kendall C, Coplen TB. 2001. Distribution of oxygen-18 and deuterium in river waters across the United States. Hydrological Processes 15:1363-93.

Kennett DJ. 2005. The Island Chumash: Behavioral Ecology of a Maritime Society. Berkeley: University of California Press. 298 p.

Kennett DJ, Voorhies B. 1995. Middle Holocene periodicities in rainfall inferred from oxygen and carbon isotopic fluctuations in prehistoric tropical estuarine mollusk shells. Archaeometry 37:157-70.

Kennett DJ, Ingram BL, Erlandson JM, Walker PL. 1997. Evidence for temporal fluctuations in marine radiocarbon reservoir ages in the Santa Barbara Channel, southern California. Journal of Archaeological Science 24:1051-9.

Kennett DJ, Ingram BL, Southon JR, Wise K. 2002. Differences in ${ }^{14} \mathrm{C}$ age between stratigraphically associated charcoal and marine shell from the archaic period site of Kilometer 4, southern Peru: old wood or old water? Radiocarbon 44(1):53-8.

Kennett DJ, Kennett JP, Erlandson JM, Cannariato KG. Forthcoming. Human responses to Middle Holocene climate change on California's Channel Islands. Quaternary Science Reviews.

Killingley JS. 1981. Seasonality of mollusk collecting determined from ${ }^{18} \mathrm{O}$ profiles of midden shells. American Antiquity 46(1):152-8.

Killingley JS, Berger WH. 1979. Stable isotopes in a mollusk shell: detection of upwelling events. Science 205:186-8

King CD. 1990. Evolution of Chumash Society: A Comparative Study of Artifacts Used for Social System Maintenance in the Santa Barbara Channel Region Before AD 1804. New York: Garland Publishing. $296 \mathrm{p}$.

Koerper HC, Jull AJT, Linick T, Toolin L. 1988. A tandem accelerator mass spectrometry (TAMS) C-14 date for a Haliotis fishhook. Pacific Coast Archaeological Society Quarterly 24(4):49-53.

Koerper HC, Prior C, Taylor RE, Gibson RO. 1995. Additional accelerator mass spectrometry (AMS) radiocarbon assays on Haliotis fishhooks from CA-ORA378. Journal of California and Great Basin Anthropology 17:273-9.

Krantz DE, Williams DF, Jones DS. 1987. Ecological and paleoenvironmental information using stable isotope profiles from living and fossil molluscs. Palaeogeography, Palaeoclimatology, Palaeoecology 58:249-66.

Krantz DE, Williams DF, Jones DS. 1989. Reply to “Aspects of growth deceleration in bivalves: clues to understanding the seasonal $\delta^{18} \mathrm{O}$ and $\delta^{13} \mathrm{C}$ record." Palaeogeography, Palaeoclimatology, Palaeoecology 70:403-7.

Mulholland SC, Prior C. 1993. AMS radiocarbon dating of phytoliths. In: Pearsall DM, Piperno DR, editors. Current Research in Phytolith Analysis: Applications in Archaeology and Paleoecology. MASCA research papers in science and archaeology, Volume 10. Philadelphia: MASCA, The University Museum of Archaeology and Anthropology, University of Pennsylvania. $\mathrm{p} 21-3$.

Pak D, Kennett JP, Kashgarian M. 1997. Planktonic foraminiferal proxies of hydrographic conditions in the Santa Barbara Basin. Eos, Transactions, American Geophysical Union 78:359.

Piperno DR, Flannery KV. 2001. The earliest archaeological maize (Zea mays L.) from highland Mexico: new accelerator mass spectrometry dates and their implications. Proceedings of the National Academy of Science 98(4):2101-3. 
Piperno DR, Stothert KE. 2003. Phytolith evidence for early Holocene Cucurbita domestication in southwest Ecuador. Science 299(5609):1054-7.

Rick TC. 2001. AMS radiocarbon dating of a shell fishhook from Santa Rosa Island, California. Radiocarbon 43(1):83-6.

Rick TC. 2005. Red abalone bead production and exchange on California's Northern Channel Islands. North American Archaeologist 25(3):215-37.

Rick TC, Vellanoweth RL, Erlandson JM, Kennett DJ. 2002. On the antiquity of the single-piece shell fishhook: AMS radiocarbon evidence from the southern California coast. Journal of Archaeological Science 29(9):933-42.

Rick TC, Vellanoweth RL, Erlandson JM. 2005. Radiocarbon dating and the "old shell" problem: direct dating of artifacts and cultural chronologies in coastal and other aquatic regions. Journal of Archaeological Science 35:1641-8.

Roark EB, Ingram BL, Southon JR, Kennett JP. 2003. Holocene foraminiferal radiocarbon record of paleocirculation in the Santa Barbara Basin. Geology 31(4): 379-82.

Robinson SW. 1980. Natural and man-made radiocarbon as a tracer for coastal upwelling processes. In: Richards FA, editor. Coastal Upwelling. Washington, D.C.: American Geophysical Union. p 298-302.

Robinson SW, Trimble D. 1981. US Geological Survey radiocarbon measurements II. Radiocarbon 23(2): $305-21$.

Santa Barbara Coastal Long-Term Ecological Research [SBC LTER]. 2003. Santa Barbara Coastal Long-Term Ecological Research, three-year progress report, Volume 1. http://sbcdata.lternet.edu/external/Documents/ Mid-termReview SBC_LTER_report_Vol_1.pdf.

Schiffer MB. 1986. Radiocarbon dating and the "old wood" problem: the case of the Hohokam chronology. Journal of Archaeological Science 13:13-30.

Shackleton NJ. 1969. Marine mollusca in archaeology. In: Brothwell D, Higgins ES, editors. Science in Archaeology. New York: Thames and Hudson. p 407-14.

Shackleton NJ. 1973. Oxygen isotope analysis as a means of determining season of occupation of prehistoric midden sites. Archaeometry 15:133-41.

Smith B. 1997. Reconsidering the Ocampo caves and the era of incipient cultivation in Mesoamerica. Latin American Antiquity 8(4):342-83.

Spiker EC. 1980. The behavior of ${ }^{14} \mathrm{C}$ and ${ }^{13} \mathrm{C}$ in estuarine water: effects of in situ $\mathrm{CO}_{2}$ production and atmospheric exchange. Radiocarbon 22(3):647-54.

Stafford TW, Hare PE, Currie L, Jull AJT, Donahue DJ. 1991. Accelerator radiocarbon dating at the molecular level. Journal of Archaeological Science 18(1):35-72

Stuiver M, Polach HA. 1977. Discussion: reporting of ${ }^{14} \mathrm{C}$ data. Radiocarbon 19(3):355-63.
Stuiver M, Braziunas TF. 1993. Modeling atmospheric ${ }^{14} \mathrm{C}$ influences and ${ }^{14} \mathrm{C}$ ages of marine samples to 10,000 BC. Radiocarbon 35(1):137-89.

Stuiver M, Reimer PJ. 1993. Extended ${ }^{14} \mathrm{C}$ database and revised CALIB $3.0{ }^{14} \mathrm{C}$ age calibration program. $R a$ diocarbon 35(1):215-30.

Stuiver M, Reimer PJ, Reimer RW. 2000. CALIB 4.3 [WWW program and documentation]. Seattle: University of Washington and Belfast: Queen's University of Belfast. URL: www.calib.org.

Stuiver M, Pearson GW, Braziunas TF. 1986. Radiocarbon calibration of marine samples back to $9000 \mathrm{cal} \mathrm{yr}$ BP. Radiocarbon 28(2B):980-1021.

Stuiver M, Reimer PJ, Bard E, Beck JW, Burr GS, Hughen KA, Kromer B, McCormac FG, van der Plicht J, Spurk M. 1998. IntCal98 radiocarbon age calibration, 24,000-0 cal BP. Radiocarbon 40(3):1041-83.

Taylor RE. 1987. Radiocarbon Dating: An Archaeological Perspective. Orlando, Florida: Academic Press. $212 \mathrm{p}$.

Taylor RE, Berger R. 1967. Radiocarbon content of marine shell from the Pacific coast of Central and South America. Science 158:1180-2.

Taylor RE, Kirner DL, Southon JR, Chatters JC. 1998. Radiocarbon dates of Kennewick Man. Science 280(5367): 1171.

Tripp JA, Hedges REM. 2004. Single-compound isotopic analysis of organic materials in archaeology. $L C$ GC North America 22(11):1098.

USGS NWIS [United States Geological Survey National Water Information System]. 2006. USGS surface-water data for the USA [WWW document]. URL: http:// waterdata.usgs.gov/nwis/sw.

Vanhaeren M, d'Errico F, Stringer C, James SL, Todd JA, Mienis HK. 2006. Middle Paleolithic shell beads in Israel and Algeria. Science 312:1785-8.

Vellanoweth RL. 2001. AMS radiocarbon dating and shell bead chronologies: middle Holocene trade and interaction in western North America. Journal of Archaeological Science 28:941-50.

Vellanoweth RL, Lambright MR, Erlandson JM, Rick TC. 2003. Early New World maritime technologies: sea grass cordage, shell beads, and a bone tool from Cave of the Chimneys, San Miguel Island, California, USA. Journal of Archaeological Science 30:1161-73.

Vogel JS, Nelson DE, Southon JR. 1987. ${ }^{14}$ C background levels in an accelerator mass spectrometry system. $R a$ diocarbon 29(3):323-33.

Wefer G, Killingley JS. 1980. Growth histories of strombid snails from Bermuda recorded in their O-18 and C13 profiles. Marine Biology 60:129-35.

Wefer G, Berger WH. 1991. Isotope paleontology: growth and composition of extant calcareous species. Marine Geology 100:207-48. 